Deviance, Dark Tourism and 'Dark Leisure': Towards a (re)configuration of morality and the taboo in secular society

Philip R. Stone, University of Central Lancashire 
Author's Final Draft - to cite this paper, please use the following reference:

Stone, P.R. and Sharpley R. (2013) 'Deviance, Dark Tourism and 'Dark Leisure': Towards a (re)configuration of morality and the taboo in secular society'. In S. Elkington and S. Gammon (Eds) Contemporary Perspectives in Leisure: Meanings, Motives and Lifelong Learning, Abington, Oxon: Routledge

For further details, visit http://www.routledge.com/books/details/9780415829892/

\section{Deviance, Dark Tourism and 'Dark Leisure': Towards a (re)configuration of morality and the taboo in secular society}

\section{Philip R.Stone and Richard Sharpley}

Leontius... was coming up from the Peiraeus... when he saw some dead bodies lying near the executioner, and he felt a desire to look at them, and at the same time felt disgust at the thought, and tried to turn aside. For some time he fought with himself and put his hand over his eyes, but in the end the desire got the better of him, and opening his eyes wide with his fingers he ran forward to the bodies, saying "There you are, curse you, have your fill of the lovely spectacle."

- Plato, The Republic IV, $360 \mathrm{BC}-$

\section{Introduction}

Travelling to meet the dead has long been a feature of the tourism-leisure landscape. In ancient times, for example, state sanctioned death and killing provided the mainstay for leisure consumption at Roman gladiatorial games. In the Middle Ages, death provided for a spectator event as journeys to witness public executions offered a valid excuse for leaving home. Moreover, during the Romantic period of the $18^{\text {th }}$ and $19^{\text {th }}$ centuries, touristic visits to deceased authors' homes, haunts, and graves were perhaps the 
most compelling technique for imaginatively contacting the dead. However, today, in a (Western) secular society where death and dying is largely sequestered and institutionalised behind medical and professional façades; death and the dead, or at least certain kinds of death and the Significant Other Dead, are mediated in the public realm for contemporary consumption (Stone, 2012). This modern mediation of mortality includes the 'darker side of travel' whereby tourists now visit commoditized sites of death which, in turn, have been packaged up and rendered into performative leisure experiences for tourism consumption (Sharpley and Stone 2009). Commonly referred to as 'dark tourism' (Lennon and Foley, 2000), tourists can now make traumascapes such as Auschwitz-Birkenau, Ground Zero, the Killing Fields of Cambodia, or Chernobyl - the site of the world's worst nuclear accident - an integral part of leisure itineraries. However, despite ethical dilemmas of the practice and processes of dark tourism, dark tourism as a contemporary leisure experience can constitute ceremonies of life and death. These, in turn, have the capacity to expand boundaries of the imagination and to provide the contemporary visitor with potentially life-changing points of shock. Indeed, dark tourism and the inherent 'leisure' experience it entails may be perceived as a rite of social passage, given its transitional elements and its potential to influence the psychology and perception of individuals (Biran et al. 2011). Furthermore, dark tourism occurs within liminal time and space and, as such, locates the activity within constructivist realms of meaning and meaning-making (Stone and Sharpley, 2008). Arguably, therefore, dark tourism provides a contemporary lens of leisure through which life and death may be glimpsed, thus revealing relationships and consequences of the processes involved that mediate between the individual and collective self.

While dark tourism as a subject for scholarly scrutiny remains theoretically and empirically fragile, the provocative and emotive nature of dark tourism in commodifying seemingly taboo topics such as death has attracted increasing academic and media attention (Stone, 2011). Much of this attention has focussed on specific aspects of the phenomenon, including for instance, dark tourism and collective memory and politics, interpretation and commodification of tragedy and atrocity, as well as exploring fundamental interrelationships between consuming dark tourism and the cultural condition of contemporary society. Particularly, however, an increasing number of critical spotlights are being shone on the moral and ethical dimensions of dark tourism, with significant moral 
commentary being generated by the media. For instance, Marcel (2004: 1) proclaimed in The American Reporter that "death makes a holiday" and, as such, "dark tourism is filled with moral ambiguities" and that it is the "dirty little secret of the tourism industry". Avis (2007) writing in the Turkish Daily News argued that dark tourism was 'sick' and, as a result, should be abolished in that it signified the moral end of humanity. Similarly, Halley (2004) commenting in The Sunday Telegraph suggests dark tourism was a negative vessel to expel our own miseries in that it allowed individuals to have a narcissistic 'therapeutic blubber' without the debilitating side-effects of having experienced actual tragedy. Meanwhile, West (2004) in his journalistic monologue Conspicuous Compassion, argues collective outpourings of grief by so-called 'grief tourists' in the aftermath of tragedy, or what he calls 'mourning sickness', is more about individuals seeking a common identity and new social bonds to replace those that have withered in the post-war era. West goes on to assert tourists' cynical use of the death of strangers in shows of public memorialisation is not about genuine empathy but mere ersatz emotion.

Debatably, what these selective moral commentaries suggest is that dark tourism is somehow aberrant in both its production and consumption of taboo topics such as death and the (re)presentation of the dead. Particularly, moral criticism and subsequent moral panic it may create is often levied at the assumed deviant nature of not only the individuals who partake in dark tourism but also, and perhaps more importantly, the apparent deviance and immorality of their (leisure) experience. Of course, deviance arrives from partaking in social and cultural taboos which, in turn, are prohibitions placed on exposing what is good as well as what is bad. Prohibited by authority or social influences, taboos are rooted in an unconscious guilt and insulated from our psychosocial life-worlds by mediating institutions of religion and politics. Yet, in an age of secularisation and liberalisation, new mediating institutions of the taboo are emerging, particularly within contemporary museology and the visitor economy. Presently, therefore, a number of time-honoured taboos, such as talk of death and presenting the dead within public places, are becoming increasingly translucent and, consequently, there is a new willingness to tackle inherently ambiguous and problematic interpretations.

However, despite criticism from an emotionally charged media of dark tourism and its interpretation of death and disaster and, subsequently, the morality of dark tourism and 
ethics of consumption, any ostensible deviance of leisure experiences within dark tourism have not been interrogated or conceptually informed. Thus, the aim of this chapter is to commence a theoretical interrogation of the interrelationships between dark tourism and the leisure experience - or what might be termed dark leisure - with notions of deviance, morality, and boundaries of the taboo. In other words, specific dark tourism experiences may be considered a facet of broader dark leisure in the touristic (re)presentation and contemporary consumption of taboos. Drawing upon and updating previous work by Stone (2009) and his analysis of constructing morality in dark tourism places, this study critically addresses the role of dark leisure experiences in the secular (re)construction and (re)configuration of the taboo, morality, and deviance. Of course, deviance is engineered by established moral codes and policed by secular and religious gatekeepers; yet deviance and the taboo it is derived from is often socially, culturally, and individually relative. Therefore, this chapter argues that the notion of deviance is currently being challenged by dark tourism and that embodied dark leisure experiences provide for a potential (re)construction of morality and a reorientation of moral codes within secular society. Consequently, the chapter suggests that against a backdrop of secularisation, provoking notions of deviance and a reconfiguration of the taboo within (new) dark leisure experiences allows contemporary morality to be confronted. Ultimately, the study contends that because the secular (re)construction of morality and the challenging of taboo boundaries in new communicative (leisure) spaces is often misconstrued as deviant; dark leisure is neither 'dark' nor 'deviant' but divergent in challenging taboo gatekeepers. However, the question remains of what is deviance in dark leisure, and it is this that the chapter now turns as a basis for subsequent discussions on reconfiguring morality and the taboo in dark tourism places.

\section{Leisure and 'Deviance': Constructions of Dark Leisure}

The thought of deviance - that is, the transgression of social, religious, and cultural orthodoxy - can titillate the imagination. Indeed, deviance is a daily bastion of popular culture in which deviant topics such as death, sex, gambling, drug use, and violence, are visually and textually offered for casual consumption (Bryant, 2011). Yet, leisure as a 
consumption activity is often lauded with 'goodness' and the benefits to participants and society. Subsequently, within the leisure literature there is an inherent bias in favour of a positivist paradigm that continues to adhere to assumptions of disembodied universals that 'prove' the existence of beneficial characteristics of leisure (Reible, 2005; Stenseng, Rise, \& Kraft, 2011). Leisure theorists often remain faithful to a moralising construction of what is good and what is bad that renders imperceptible leisure activities that might be deemed 'deviant'. Inherent in this imperceptibility are concomitant, if not naïve, assumptions that only 'normal' or 'legitimate' leisure is beneficial to society, essential to wellbeing, a means of providing an opportunity to find truth, freedom, and beauty, and which are embedded with meaning (Rojek, 1999a). Of course, leisure activity in this context is concerned with reinforcing and maintaining social order or improving social conditions (Rojek, 1999a). Yet, arguably, such a view has limitations in understanding individual meanings in collective leisure settings, as well as limiting understanding of what might be considered popular 'deviant' activities. As a result, discourse on 'deviant leisure' - that is, dichotomies between what is considered negative or immoral leisure activity and that which is considered legitimate - has received increasing academic attention (Rojek, 1999b).

Disentangling concepts of leisure and deviance is extremely difficult and contentious, and has even warranted academic debate on fallacious 'leisure' activities such as serial killing and murder (Rojek, 1999c; Gunn \& Caissie, 2002). While such discourse is unhelpful in extricating deviance in what might be considered mainstream leisure, leisure is not a definite category of social behaviour (Horna, 1994). Unsurprisingly, therefore, a lack of consensus in defining what is and what is not deviant leisure assumes that deviant leisure relates to a negative and immoral activity (Stebbins 1996;, Stebbins, Rojek, \& Sullivan, 2006). In other words, deviant leisure may be deemed 'deviant' in violating common and accepted norms of behaviour and society (Bryant, 2011). Importantly, however, leisure which is socially constructed as 'deviant' dispossesses those who choose to participate in it. Moreover, the social and cultural construction of deviant leisure lies in the central assumptions of its origin, the lexicon used to describe and discuss it, the perceptions of the beholder, and the rules and sanctions enforced by those with hegemonic power. Consequently, deviant leisure can provide the backdrop for the formation of identity, for finding a sense of being and purpose in a secular and fragmented world, or for rejecting 
religion, conformity and creating alternative cultural values. As Rojek (1999a) suggests, deviant leisure serves to exhibit distain and to reject social controls that otherwise would eliminate it. In short, deviant leisure is not inherently deviant but is relative both as a perception as well as a cultural practice.

However, while deviant leisure may be a subset of leisure, which is informed by sociology and social psychology, it has its conceptual origins in deviance - and deviance has been medicalized. As Conrad and Schneider (1992) note, the medicalization of deviance is not a morally neutral approach to gathering knowledge but, rather, an approach that reflects an epistemological shift from 'badness to sickness'. Williams (2009) goes on to argue that deviant leisure tends to rely heavily on Western Judeo-Christian perspectives and psychiatric and forensic discourses. As a result, deviant leisure is often assumed to be bad, pathological, dangerous or even criminal. Of course, while this study does not dismiss these assumptions, the increasing recognition of the complexity of deviant leisure calls for a widening of what might constitute legitimate 'healthy' or 'positive' deviant leisure and the processes involved in its constitution (Biran \& Poria, 2012). Particularly, Williams (2009) argues many forms of deviant leisure, when additional methods and disciplines are considered, may be viewed as legitimate healthy experiences. Arguably, therefore, those dark leisure experiences located within dark tourism, which as noted earlier are often perceived as morally suspect and deviant by an unfettered media, might be viewed as legitimate and healthy when the broader cultural condition of secular society is taken into account. In other words, against a backdrop of contemporary society and culture, dark leisure which might be construed as deviant by some may have positive, if not fundamental, characteristics. This is particularly so when secular society has cultivated a process of individualisation, whereby the individual self feels isolated and morally confused due to the negation of dominant religious and moral frameworks. Consequently, as individuals attempt to seek (moral) meaning on their own terms and from alternative cultural institutions (such as tourism and leisure), new moral orders are mediated by collectivities of embodied individuals who are emotionally engaged with their social world. Thus, it is these embodied dark leisure experiences which add to a potential reconfiguration of morality within secular society that this chapter now turns. 


\section{Secularisation, Individualism and Moral Confusion - The Role of 'Dark Leisure'}

The issue of morality, as defined by good or bad conduct, has been subject to increasing scrutiny by those interested in its purpose, especially within the ambivalent character of contemporary society (Stone, 2009). Consequently, an increasing secularisation of modern (Western) societies has given rise to fundamental questions of religion, morality and the moral frameworks in which we are located. Indeed, an increasing rejection of institutionalised religion as a formal framework for social and cultural control raises the notion of not only religiosity, but also how the moral well-being of the individual self can be met within an ever fragmented and polarised world. Moreover, questions of moral wellbeing in contemporary society become more pronounced when established taboos such as the representation of death are tested and religious gatekeepers are challenged. Thus, as "secularisation is an inevitable outcome of social processes, which causes a realignment of the entire social fabric" (Oviedo, 2005), the sacred canopy (after Berger, 1967) which once embraced society and provided for an overarching meaning system in terms of moral endeavours, has become fractionalised. However, secularisation is not a simple, onedimensional transformation of a sacred world-view into a profane one. Instead, it is "a complex process of reconfiguration that re-invents, translates, or cites moments of sacrality in a new concept" (Skolnick \& Gordon, 2005: 7). Certainly, one key aspect of contemporary society and the secular values attached to it has been to detach individuals, or at least loosen them, from any sense of obligation which they may have felt towards traditional and established religious institutions which previously had provided a dominant framework in which to find meaning and moral guidance. Indeed, individualisation is regarded as one of the most important processes to have dramatically changed society (Beck \& BeckGernsheim, 2002). As a result, the individual self has become free and independent from traditional, social and religious foundations. Thus, the emphasis on individual freedom lessens the control and influence of traditional institutions upon society, whereby institutional religion has become polarised and personalised. As Halman (1996: 199) states, "religious and moral values are no longer imposing themselves on societies".

However, individualisation should not be confused or equated with individualism; as Halman (1996: 198) points out, "individualisation denotes a process in which traditional meaning systems and values diminish in importance in favour of personal considerations 
and decisions concerning values, norms and behaviours". Individualism, meanwhile, focuses on the individual's self-development, convictions and attitudes as the basis upon which to make decisions, whereby individual ethics are (morally) relative (Harman, 1975). Arguably, however, increased individualism which has resulted from individualisation, combined with a reduced scope of the sacred, has resulted in moral confusion for the individual self. In other words, the lack of a consistent framework of substantive norms, values or moral principles to define and understand personal identity leaves many individuals feeling disoriented. Moreover, when taboo boundaries are pushed ever forward for contemporary tourism consumption and, potential deviant labels being assigned to both the process and practice of dark leisure; this disorientation takes on added significance. Therefore, the process of individualisation has made people more reliant upon themselves for moral instruction and less dependent on traditional institutions which, in turn, raise issues of how individuals within contemporary society seek and utilise (moral) meanings from nontraditional institutions.

Hence, if we accept the individual self, as a result of secular inspired individualism, is experiencing moral confusion and disorientation, then the self must begin to seek meanings and identity formulation in a complex and fragmented world. Conventional religious institutions which once provided moral space, both in the mind of the individual self and as a physical outlet for moral reflection and guidance, have largely been negated. In its place is a post-conventional society that demands "an open identity capable of conversation with people of other perspectives in a relatively egalitarian and open communicative space" (Hyun-Sook, 2006: 1). It is these new communicative spaces that we must consider in framing contemporary approaches to morality (Stone, 2009). Above all, if we view dark leisure in its various manifestations within dark tourism as contemporary communicative encounters which dialogically interpret tragic events and, subsequently, convey a sense of morality, then we can adopt a multidimensional approach towards constructing morality. Ultimately, however, dark leisure experiences and the ensuing moral dilemmas which surround them often result in a vibrant discussion of not only the taboo topic represented, but also the actual (re)presentation itself. This, in turn, could potentially inform contemporary moral instruction to the individual self, and it is this point that this chapter now turns. 


\section{Reconfiguring Morality and the Taboo through Dark Leisure}

The process and consequences of dark leisure as a mediating force in (re)constructing morality and influencing the boundaries of established taboos can greatly benefit from engaging with the philosophy of Emile Durkheim. In his seminal text, The Elementary Forms of Religious Life, Durkheim (2001 [1912]) developed a deep concern with society as a moral, religious force which stimulated in people an effervescent propulsion towards actions productive of either social cohesion or dissolution. Termed by Durkheim as collective effervescence, the asocial capabilities of the embodied individual, as well as the potentialities of embodied humans at the collective level meant that boundaries of morality can be shifted, translated, and (re)invented by people engaging with their social world (Shilling, 2005). As Shilling and Mellor (1998: 196) note, "it is the collective effervescence stimulated by assembled social groups that harnesses peoples' passions to the symbolic order of society". Thus, the emotional experience of these assembled social groups allows individuals to interact on the basis of shared ideas and concepts. Fundamentally, the concept of effervescence and its consequent emotional 'rush of energy' (Durkheim, 2001 [1912]: 215) permits social gatherings to infuse individuals and, thus, for people to become embodied and informed about particular tragic events that may have perturbed their lifeworld. Hence, collective effervescence has the potential to substitute the world immediately available to our perceptions for another, more moral world (Durkheim, 2001 [1912]). It is this gathering of social groups within secular society, often in socially sanctioned environments, such as in the case of dark tourism, that a contemporary reality of la société is observed (Stone, 2009). Indeed, the social binding of individuals by dark leisure experiences in subtle, if not quiet emotional effervescence influences and informs moral conversations about death or disaster, whereby the self can extract individualized and thus morally relative meaning about a particular tragic event (Stone, 2009). Particularly, in the case of violent events, or where communities have suffered disaster, Durkheim (2001: 3023) suggests a collective response has implications for the individual:

When emotions are so vivid, they may well be painful but they are not depressing. On the contrary, they indicate a state of effervescence that suggests a mobilization of all our active forces and even an influx of external agencies. It matters little that this exaltation was provoked by a sad event; it is no less real and does not differ 
from the exaltation observed in joyous festivals.... Just by being collective, these ceremonies raise the vital tone of the group.... thus they are reassured, they take heart, and subjectively it is as though the rite really had repelled the dreaded danger.

Consequently, a Durkheimian perspective allows for an understanding of the construction of secular moral orders as mediated by collectives of embodied individuals who are both cognitively and emotionally engaged with their social world (Shilling and Mellor 1998; Shilling 2005). However, whilst Durkheim's insight of morality was an expression of what was perceived to be sacred, a contemporary application of Durkheim's work goes beyond that of the relationship between religion and morality. When applied to contemporary assembled social groups and experiences thereof, such as those which exist in some dark tourism sites, it is suggested that inherent dark leisure experiences influence and inform, thus allowing the self to become embodied about the tragic event which they are consuming. This may result, in relative terms at least, in a transformation of personal emotional insights and moral orders. In other words, morality is generated, maintained, challenged or confirmed within these new vitalized leisure spaces, albeit with varying degrees of intensity, through embodied individuals who are engaged with their secular and individualized life-worlds. In turn, this stimulates a kind of collective emotional energy, or effervescence, which socially binds individuals through their consumption of dark leisure experiences. Consequently, it is this, the fact that individuals collectively assemble in seemingly 'dark spaces' and gaze upon sordid human activity, or collectively consume grief and tragedy, that is often reported upon by the media as 'moral panic' or somehow deviant (Seaton and Lennon, 2004). However, fundamentally, this apparent deviant kind of leisure is not as unequivocal as some media reporting might assume. Indeed, when examined from a Durkheimian perspective, the deviance dark leisure experiences seemingly provoke might be viewed as ethically relative to the individual but, at the collective level, has profound implications for secular society in its attempt to create and maintain new moral frameworks through the expansion and testing of taboo boundaries. In short, the perceived deviance of leisure behaviour in dark tourism is the consequence of discourse generated by dark tourism practice and the taboo it seeks to represent. Consequently, deviance as in deviant leisure is not the end result of dark leisure, but merely a symptom of secular society 
attempting to negotiate and mediate morality in new communicative spaces. Indeed, it is against a backdrop of individualization and construction of new secular moral orders, that the communication and negotiation of 'moral meaning' within collective contemporary 'dark spaces' is often misconstrued as deviant. Quite simply, there is no deviance as a result of dark leisure experiences, only talk of deviant behaviour. It is this 'talk', frequently conveyed by media commentaries of dark tourism, which is an integral element of the social effervescence that reconfigures and translates moralities which surround the contemporary consumption of death, disaster and tragedy.

\section{Conclusion}

This chapter arises from a simple yet fundamental interest in the social and cultural construction of morality within secular society and the interrelationships of contemporary leisure experiences. Therefore, this chapter set out to enhance the theoretical foundations of the dark tourism phenomenon and inherent 'dark leisure' experiences by considering them within a broader framework of emotion and morality. In so doing, the study has not only developed a conceptual basis for the future empirical testing of ethics and morality within dark leisure experiences, but has also contributed to a wider social scientific understanding of morality within contemporary societies.

The summative model in Figure 1 illustrates a number of emergent issues from this chapter. Firstly, secularization and the negation of religion as a traditional dominant framework, in which meaning and moral guidance is provided, has seemingly left some individuals isolated, disoriented and morally confused. Secondly, as post-conventional societies cultivate a process of individualization and moral confusion, individuals seek morally relative meaning on their own terms and from non-religious and non-traditional institutions, enabling dark tourism places in their representation of taboo topics to become contemporary communicative spaces. Thirdly, individuals collectively assemble in these new communicative (dark) spaces, resulting, potentially, in both the provision and extraction of moral meaning about a particular tragic event, which in turn allows the self to become embodied through a dark leisure experience. Finally, collective effervescence and its resultant emotional energy is discharged through and by embodied individuals within these 
new socially sanctioned dark spaces, whereby morality is conveyed not only by official interpretation of the death or tragedy, but also by the actual presence and emotional engagement of the individual visitor. This, in turn, can be interpreted by the media and other commentators as moral panic or deviant behaviour which, to them at least, means an apparent dissolution of ethics at the collective level. In short, dark leisure may provide new communicative encounters in which not only is immorality and taboos (re)presented for contemporary consumption, but also in which morality is communicated, reconfigured and revitalized. This reconfiguration and revitalization of moral issues through dark leisure is not deviant, nor should it generate discourse about deviance, but instead it should be viewed as a process of contemporary society in which we renegotiate moral boundaries and ethical principles through consuming the taboo. Therefore, it is, perhaps, the process of dark tourism which attracts individuals to consume death in new insulating spaces that generates a perceived deviance, in addition, or even rather than, the actual death, disaster or tragedy that dark tourism seeks to represent.

Of course it would be naïve to advocate that the process of dark tourism, both in its production and consumption, provides for defining communicative encounters for contemporary moral instruction. It does not. Given the extensive and complex array of dark tourism sites in a variety of social, cultural and political contexts, actual dark leisure experiences will no doubt both provide and be provided with a myriad of potential moral meanings. Nonetheless, locating dark tourism and concomitant dark leisure within a broader conceptual emotion-morality framework allows for moral orders and their construction within contemporary society to be interrogated. Dark leisure is neither deviant nor dark in the usual accepted sense, but an often widely reported upon, if not misunderstood phenomenon. Indeed, dark leisure challenges the very idea of deviance within deviant leisure as well as the gatekeepers who maintain the concept. In conclusion, however, the primary complication remains in that leisure researchers appear to have difficulty in extricating themselves from the socialization that has allied deviant leisure practices with immorality, psychopathology, and dangerousness. Whilst this socialization is entrenched and pervasive, this study advocates that future deviant/dark leisure research becomes more attuned with how social, cultural, historical, and political influences shape perceptions of morality, taboos, and deviance. Indeed, deviance is not always what it first appears. Within a dark leisure context, so-called deviance can embody and even strengthen 
notions of human connectivity, translate and reconfigure boundaries of morality and, ultimately, create ontological meanings for the secular self. 

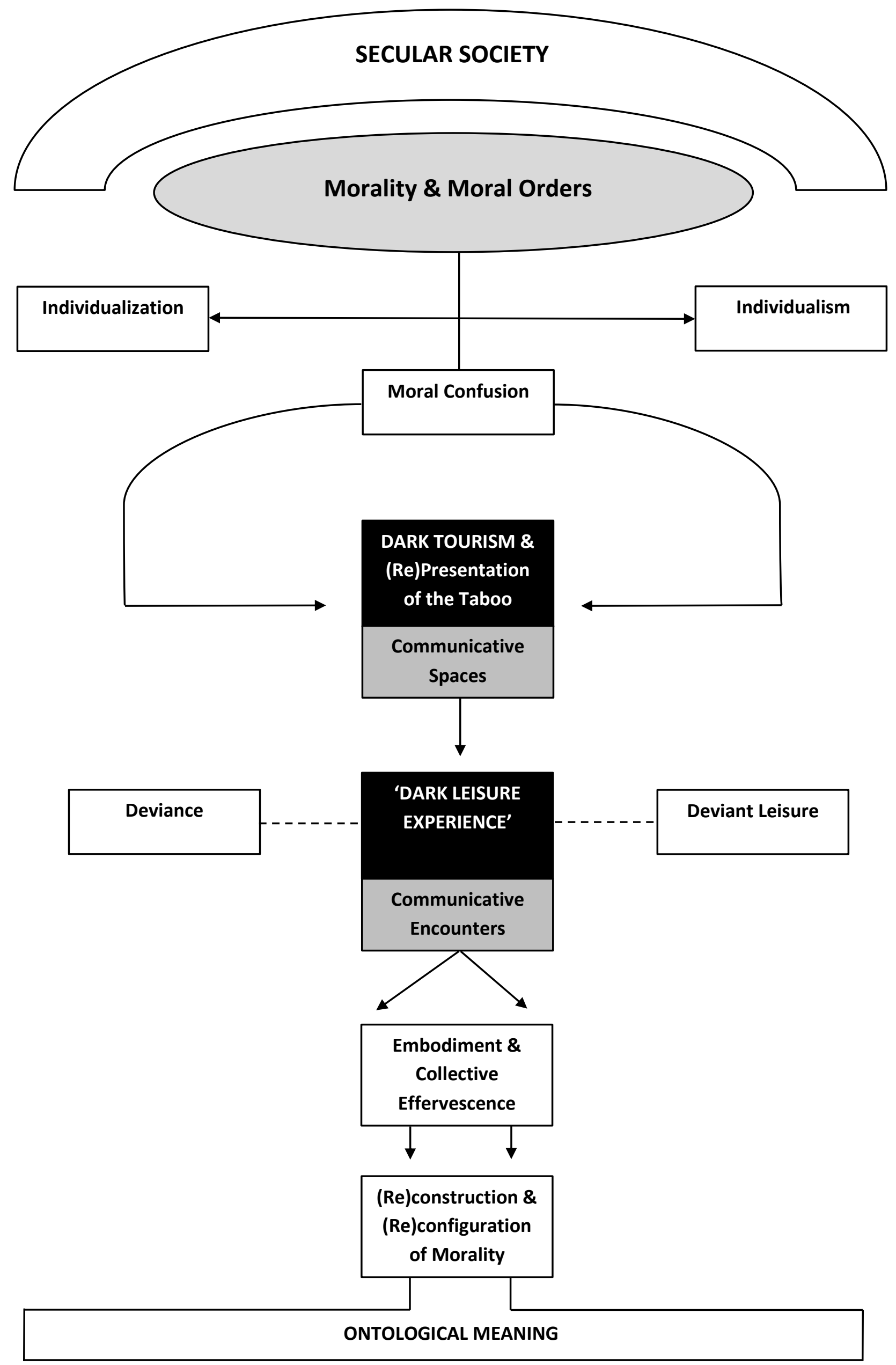

Figure 1: A conceptual model of dark leisure experiences and the 


\section{References}

Avis, A. (2007) Seek, so you may find. Turkish Daily News, November 3, http://www.turkishdailynews.com.tr/article.php?enewsid=87581 (Accessed: 05/02/13).

Beck, U. and Beck-Gernsheim, E. (2002) Individualization: Individualism and its Social and Political Consequences. London: Sage.

Berger, P. (1967) The Sacred Canopy: Elements of a Sociological Theory of Religion. New York: Doubleday.

Biran, A. and Poria, Y. (2012) Reconceptualising Dark Tourism. In R.Sharpley and P.R.Stone (Eds) Contemporary Tourist Experience: Concepts and Consequences, pp. 59-70. Abington, Oxon: Routledge.

Biran, A., Poria. Y., \& Oren, G. (2011). Sought Experiences at (Dark) Heritage Sites. Annals of Tourism Research, 38(3), pp. 820-841.

Bryant, C.D. (Ed) (2011) The Routledge Handbook of Deviant Behaviour. London: Routledge. Conrad, P. and Schneider, J. (1992) Deviance and medicalization: From badness to sickness. Philadelphia: Temple University Press.

Durkheim, E .(2001 [1912]) The Elementary Forms of Religious Life (translated by C. Cosman). Oxford: Oxford University Press.

Gunn, L. and Caissie, L.T. (2002) Deviant Leisure and Serial Murder: Exploring the Unknown. Tenth Canadian Congress on Leisure Research, University of Alberta, Edmonton, Alberta, May 22-25.

Halley, G, (2004) Grief tourists lap up other people's pain. The Sunday Independent (Ireland), March 14.

Halman, L. (1996) Individualism in individualized society? Results from the European Values Surveys. International Journal of Comparative Sociology,37(3-4), 195-214.

Harman, G. (1975) Moral Relativism Defended. The Philosophical Review 84(1), 3-22.

Horna, J. (1994). The study of leisure: An introduction. Toronto: Oxford University Press.

Hyun-Sook, K .(2006) Educating in a post-conventional society. Religious Education, Fall: http://findarticles.com/p/articles/mi qa3783/is 200610/ai n17194917?tag=artBody;col1 (Accessed: 15/01/13).

Lennon, J. \& Foley. (2000) Dark Tourism: The Attraction of Death and Disaster. London: Continuum.

Marcel, J. (2004) Death makes a holiday. The American Reporter January 21, Vol 10(2273). 
Oviedo, L. (2005) Whom to blame for the charge of secularization? Zygon, 40(2): 351-361.

Reible, H. L. (2005) Deviant Leisure: Uncovering the 'Goods' in Transgressive Behaviour. Eleventh Canadian Congress on Leisure Research, Malaspina University-College, Nanaimo, B.C., May 17-20.

Rojek, C. (1999a) Leisure and Culture. New York: St.Martin's Press.

Rojek, C. (1999b) Deviant Leisure: the dark side of free-time activity. In E.L. Jackson and T.L. Burton (Eds), Leisure Studies: prospects for the XXI century, pp. 81-94, State College, PA: Venture Publishing.

Rojek, C. (1999c) Abnormal leisure: Invasive, mephitic, and wild forms. Society and Leisure, 22(1), pp. 21-37.

Seaton, A. and Lennon, J. (2004) Moral panics, ulterior motives and alterior desires: thanatourism in the early 21st Century. In T. Singh (ed.) New Horizons in Tourism: Strange Experiences and Stranger Practices, Wallingford: CABI Publishing, pp. 63-82.

Sharpley, R. \& Stone, P.R. (eds) (2009) The Darker Side of Travel: The Theory and Practice of Dark Tourism. Aspects of Tourism Series, Bristol: Channel View Publications.

Shilling, C. (2005) Embodiment, emotions and the foundations of social order: Durkheim's enduring contribution. In J. Alexander and P. Smith (eds.) The Cambridge Companion to Durkheim, Cambridge: Cambridge University Press, pp. 211-238.

Shilling, C. and Mellor, P. (1998) Durkheim, morality and modernity: collective effervescence, Homo Duplex and the sources of moral action. The British Journal of Sociology, 49(2). 193-209.

Skolnick, J. and Gordon, P. (2005) Editor's Introduction: secularization and disenchantment. New German Critique 94, 3-17.

Stebbins, R. (1996). Tolerable differences: Living with deviance (2nd ed.). Toronto: McGrawHill Ryerson Limited.

Stebbins, R.A., Rojek, C., and Sullivan, A.M. (Eds) (2006) Leisure/Loisir, 30, pp.3-231.

Stenseng, F., Rise, J. and Kraft, P. (2011) The dark side of leisure: obsessive passion and its covariates and outcomes. Leisure Studies, 30(1), pp. 49-62.

Stone, P.R. \& Sharpley, R. (2008) Consuming Dark Tourism: a thanatological perspective. Annals of Tourism Research, 35(2), pp.574-595.

Stone, P.R. (2009). Dark Tourism: Morality and New Moral Spaces. In R.Sharpley and P.R.Stone (Eds) The Darker Side of Travel: The Theory and Practice of Dark Tourism, (pp. 5672), Aspect of Tourism Series, Bristol: Channel View Publications. 
Stone, P.R. (2011) Dark Tourism: towards a new post-disciplinary research agenda. International Journal of Tourism Anthropology, 1(3/4), 318-332.

Stone, P.R. (2012) Dark Tourism and Significant Other Death: Towards a model of mortality mediation. Annals of Tourism Research, 39(3), pp. 1565-1587.

West, P. (2004). Conspicuous Compassion: When sometimes it really is cruel to be kind. London: CIVITAS.

Williams, D.J. (2009) Deviant Leisure: Rethinking 'The Good, the Bad, and Ugly'. Leisure Sciences, 31, pp.207-213. 